\title{
Ayurveda: The Conventional Indian Medicine System and its Global practice
}

Available online at www.ijistweb.com

\section{REVIEW ARTICLE}

\section{Snehal Shah}

Umedica Laboratories Pvt. Ltd., GIDC, Vapi, Gujarat, India.

*Corresponding Author's E-mail: snehalshah462@gmail.com

DOI: $10.22270 /$ ijist.v4i1.36

\begin{abstract}
The word "Ayurveda" meaning knowledge of life and longevity.

Rather than frequent usage of Medicines in common disorders, Ayurvdic medicines are as good as food which serve role of the nutritional needs. Because of the changing in life style and carelessness towards sickness with respect to time as well as money, people are growing modernization some traditional ways. Now a days, There has been increased global interest in traditional medicine.

In this dissertation, attempted to brief history along with worldwide concepts of Ayurveda and availability of Ayurvedic medicines which play roles in medical emergency, surgical emergency and traditional one as nutrition supplement. Moreover, WHO contribution in global acceptance of Ayurveda reflected in this paper reveals worldwide usage of Ayurveda medicines.

Opportunity and challenges with global perspective of Ayurvedic medicine and gold time for modernization presented in this concept paper gives idea about market value for herbal medicines.
\end{abstract}

Keywords: Ayurveda, WHO, Neutraceuticals, BCE, TRM.

\section{Introduction}

\section{History of Indian Traditional Medicine: A Medical Inheritance}

All traditional medicines are of its own regional effects and dominant in the West Asian nations; India, Pakistan, Tibet, and so forth, East Asian nations; China, Korea, Japan, Vietnam, and so forth, Africa, South and Central America. The universal argument between modern medicine and traditional medicines exist in the market since long back, however therapeutic knowledge of Indian traditional medicine has propelled various traditional approaches with various theories and methodologies, which are of regional significance (1).

According to modern Ayurvedic sources, the origins of Ayurveda have been traced to around 6,000 BCE. The first recorded forms of Ayurveda as medical texts evolved from the Vedas. Ayurveda is a discipline of the upaveda or "auxiliary knowledge" in Vedic tradition. The origins of Ayurveda are also found in Atharvaveda described as magical cures for disease.
There are three principal early texts on Ayurveda.

1. The Charaka Samhita,

2. The Sushruta Samhita and

3. the Bhela Samhita.

\section{Illnesses portrayed}

Following are illness portrayed and recovered by means of Ayurvedic traditional medicines.

Fever, cough, consumption, diarrhea, dropsy, abscesses, seizures, tumours, and leprosy and that treatments included plastic surgery, lithotomy, tonsillectomy, couching (a form of cataract surgery), puncturing to release fluids in the abdomen, extraction of foreign bodies, treatment of anal fistulas, treating fractures, amputations, cesarean sections, and stitching of wound The use of herbs and surgical instruments became widespread. During this period, treatments were also prescribed for complex ailments, including angina pectoris, diabetes, hypertension, and stones (2).

\section{Further development and spread}

Ayurveda flourished throughout the Indian Middle Ages. Dalhana (fl. 1200), Sarngadhara 
(fl. 1300) and Bhavamisra (fl. 1500) compiled works on Indian medicine. The medical works of both Sushruta and Charaka were also translated into the Chinese language in the 5th century and during the 8th century, they were translated into the Arabic and Persian language. The 9th-century Persian physician Muhammad ibn Zakariya al-Razi was familiar with the text. The Arabic works derived from the Ayurvedic texts eventually also reached Europe by the 12th century. In Renaissance Italy, the Branca family of Sicily and Gaspare Tagliacozzi (Bologna) were influenced by the Arabic reception of the Sushruta's surgical techniques.British physicians traveled to India to observe rhinoplasty being performed using native methods, and reports on Indian rhinoplasty were published in the Gentleman's Magazine in 1794. Instruments described in the Sushruta Samhita were further modified in Europe.Joseph Constantine Carpue studied plastic surgery methods in India for 20 years and, in 1815, was able to perform the first major rhinoplasty surgery in the western world, using the "Indian" method of nose reconstruction. In 1840 Brett published an article about this technique. During the period of colonial British rule of India, the practice of Ayurveda was neglected by the British Indian Government, in favor of modern medicine. After Indian independence, there was more focus on Ayurveda and other traditional medical systems. Ayurveda became a part of the Indian National health care system, with state hospitals for Ayurveda established across the country (3).

\section{Worldwide Concepts and thoughts for Ayurveda.}

\section{Worldwide Concepts}

Ayurveda is a system of medicine with historical roots in the Indian subcontinent Globalized and modernized practices derived from Ayurveda traditions are a type of medicine. Ayurveda developed significantly during the Vedic period and later some of the non-Vedic systems such as Buddhism and Jainism also developed medical concepts and practices that appear in the classical Ayurveda texts. Ayurveda treatises describe three elemental doṣas viz. vāta, pitta and kapha, and state that equality (Skt. sāmyatva) of the doṣas results in health, while inequality (vișamatva) results in disease. Ayurveda treatises divide medicine into eight canonical components.

\section{Eight Components:}

The earliest classical Sanskrit works on Ayurveda describe medicine as being divided into eight components. This characterization of the physicians' art, "the medicine that has eight components" (Skt.cikitsāyāmaștāangāyām), is first found in the Sanskrit epic the Mahābhārata, ca 4th century

BCE. The components are:

- Kāyacikitsāa: general medicine, medicine of the body.

- Kaumāra-bhrtya: the treatment of children, paediatrics

- Śalyatantra: surgical techniques and the extraction of foreign objects

- Śālākyatantra: treatment of ailments affecting ears, eyes, nose, mouth, etc. ("ENT")

- Bhūtavidyā: pacification of possessing spirits, and the people whose minds are affected by such possession

- Agadatantra: toxicology

- Rasāyanatantra: rejuvenation and tonics for increasing lifespan, intellect and strength

- Vājīkaranatantra: aphrodisiacs and treatments for increasing the volume and viability of semen and sexual pleasure.

\section{Composition, Principle and Terminology}




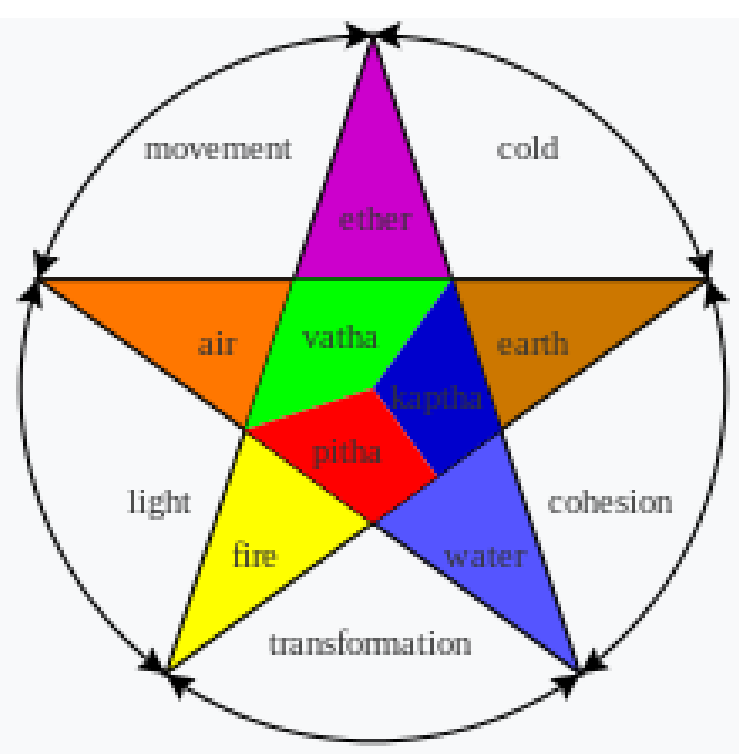

Figure 1. The three doshas and the five elements from which they are composed.

Table 1 Composition for Ayurvedic medicine consist of following components

\begin{tabular}{|c|c|c|c|}
\hline Tissues & $\begin{array}{l}\text { Bodily Substances } \\
\text { Ayurveda has historically } \\
\text { divided bodily substances } \\
\text { into five classical elements : } \\
\text { (Sanskrit) panchamahabhuta }\end{array}$ & $\begin{array}{l}\text { inherent } \\
\text { gunas (qualities } \\
\text { or } \\
\text { characteristics) }\end{array}$ & $\begin{array}{l}\text { three elemental } \\
\text { bodily humors }\end{array}$ \\
\hline $\begin{array}{l}\text { (dhatu), which are } \\
\text { plasma (rasa), blood } \\
(\text { rakta), muscles } \\
(\text { māmsa), fat (meda), } \\
\text { bone } \\
\text { (asthi), marrow (majja), } \\
\text { and semen (shukra). }\end{array}$ & $\begin{array}{l}\text { Earth, water, fire, air and } \\
\text { ether. } \\
\text { the doshas (called Vata, Pitta } \\
\text { and Kapha) }\end{array}$ & $\begin{array}{l}\text { Organized in ten } \\
\text { pairs: heavy/light, } \\
\text { cold/hot, } \\
\text { unctuous/dry, } \\
\text { dull/sharp, } \\
\text { stable/mobile, } \\
\text { soft/hard, non- } \\
\text { slimy/slimy, } \\
\text { smooth/coarse, } \\
\text { minute/gross, and } \\
\text { viscous/liquid. }\end{array}$ & $\begin{array}{l}\text { the doshas (called } \\
\text { Vata, Pitta and } \\
\text { Kapha) }\end{array}$ \\
\hline \multicolumn{4}{|c|}{$\begin{array}{l}\text { These are organized in Ama (a Sanskrit word meaning "uncooked" or "undigested") is used to refer } \\
\text { to the concept of anything that exists in a state of incomplete transformation. With regards to oral } \\
\text { hygiene, it is claimed to be a toxic byproduct generated by improper or incomplete digestion. The } \\
\text { concept has no equivalent in standard medicine. }\end{array}$} \\
\hline
\end{tabular}

\section{Principle: How they work}

Three elemental bodily humors the doshas (called Vata, Pitta and Kapha), and states that a balance of the doshas results in health, while imbalance results in disease. One Ayurvedic view is that the doshas are balanced when they are equal to each other, while another view is that each human possesses a unique combination of the doshas which define this person's temperament and characteristics. In either case, it says that each person should modulate their behavior or environment to increase or decrease the doshas and maintain their natural state.

How to practice

Ayurvedic doctors regard physical existence, mental existence, and personality as a unit, with each element being able to influence the others. This is a holistic approach used during diagnosis and therapy, and is a fundamental aspect of Ayurveda. Another part of Ayurvedic treatment says that there are channels (srotas) 
which transport fluids, and that the channels can be opened up by massage treatment using oils and Swedana (fomentation). Unhealthy, or blocked, channels are thought to cause disease.

\section{Diagnosis approach}

Ayurveda has eight ways to diagnose illness by means of five senses, called Nadi (pulse), Mootra (urine), Mala (stool), Jihva (tongue), Shabda (speech), Sparsha (touch), Druk (vision), and Aakruti (appearance)

\section{Treatment and prevention}

Ayurveda focuses on exercise, yoga, and meditation. One type of prescription is a Sattvic diet.

Ayurveda follows the concept of Dinacharya, which says that natural cycles (waking, sleeping, working, meditation etc.) are important for health. Hygiene, including regular bathing, cleaning of teeth, tongue scraping, skin care, and eye washing, is also a central practice.

\section{Substances used}

-Plant-based treatments in Ayurveda may be derived from roots, leaves, fruits, bark, or seeds such as cardamom and cinnamon.

- Animal products used in Ayurveda include milk, bones, and gallstones. In addition, fats are prescribed both for consumption and for external use. Consumption of minerals, including sulphur, arsenic, lead, copper sulfate and gold, are also prescribed. The addition of minerals to herbal medicine is called rasa shastra.

-Ayurveda uses alcoholic beverages called Madya, which are said to adjust the doshas by increasing Pitta and reducing Vatta and Kapha Madya are classified by the raw material and fermentation process, and the categories include: sugar-based, fruit-based, cereal-based, cereal-based with herbs, fermentated with vinegar, and tonic wines.

-Purified opium is used in eight Ayurvedic preparations and is said to balance the Vata and Kapha doshas and increase the Pitta dosha.

\section{Research}

In India, research in Ayurveda is undertaken by the Ministry of AYUSH, an abbreviation for the Department of Ayurveda, Yoga and Naturopathy, Unani, Siddha and Homoeopathy, through a national network of research institutes.

In Nepal, the National Ayurvedic Training and Research Centre (NATRC) researches medicinal herbs in the country.

In Sri Lanka, the Ministry of Health, Nutrition and Indigenous Medicine looks after the research in Ayurveda through various national research institutes. (4)

\section{Indian traditional medicines available in Ayurveda}

\section{Medical Emergencies available in Ayurveda}

There are certain embarrassing symptoms in fever.

These conditions are:-

(1) Tandrika Sannipat Jwara Bhava Typhoid state

(2) Prelapaka Sannipat Jwara Bhava Febrile delibrium

(3) Akshapaka Sannipat Jwara Bhava Febrile Conbuleions

(4) Karnika Sannipat Jwara Bhava Infective Parotifisa Mumps

(5) Teevre Sannipat Jwara Bhava Hyperpyrekia

(6) Sheetanja Sannipat Jwara Bhava Subnormal Temperature or Crisis

(7) Swasa-santamaka or Pratamaka Dyspnea with fever

(8) Shoola Painful condition

(9) Anidra Sleeplessness

(10) Antarlohita and many other

Table 2 Different types of Jwara (Pyroxies)

Name Reference 


\begin{tabular}{|lll|}
\hline Santata Jwara & All books & Continuous fevers like Typhoid etc. \\
\hline $\begin{array}{l}\text { Karkataka Sannipat or } \\
\text { Swasanaka Jwara }\end{array}$ & Bhava - Mishra & Pneumonia \\
\hline Abhinijasa Jwara & $\begin{array}{l}\text { Swashrat and } \\
\text { Bhavprakash }\end{array}$ & $\begin{array}{l}\text { Cerebro-spinal fevers like maningins } \\
\text { encapphalin's etc. }\end{array}$ \\
\hline Kanthakalya Sannipat & Bhavaprakash & Dyphoria \\
\hline $\begin{array}{l}\text { Sandhija Jwara (Sandhika } \\
\text { Jwara) }\end{array}$ & Bhavaprakash & Ruametic fever \\
\hline Jwaratisara & Bhavaprakash & Fever with Diarrhea \\
\hline Kotha - Jwara & Bhavaprakash & Eruptive fevers \\
\hline
\end{tabular}

\section{Surgical Emergencies}

There are certain emergencies, which require surgical treatment. The surgical emergencies are:-

(1) Sadhovrana Ulcers and wounds mostly accidental

(2) Bhagna

Fractures \& dislocation

(3) Antra-Vriddhi

Irsedulstid hernia

(4) Agantu and

Stamgulstid hernia

Pranasta Shalya

Foreign bodies

(5) Visarpa

Cellunis \& crysepelas

(6) Diseases of nose

Nosa Shalya mogets

Nasa Krimi

\section{Gynecological Emergencies}

(1) Abrijdara Ch.Chi. 30 Menorrahagia \& metrorlegha

(2) Gharbhasharva \& Garbhapata

8 Abortion \& Misearraige

Ch. Sha.

(3) Pushpa - darshan Ch. Sha. 8

Threatened abortion

(4) Garbhini Rogas Ch. Sha. 8 Diseases during Pregnancy

(5) Moodha - Garbha Su. Ni. labour

Difficult

\section{Medico-legal Emergencies}

As suggested, it is advisable not to treat the cases where medicolegal complications may arise, unless authorized, still a physician may have to attend such cases. In this condition, a physician should be careful to inform proper authorities and should be careful in history taking and examination of the patient because he may have to be present before the court of law for evidence, such emergencies are :-

(1) Agni - dagdha Burns and seals

(2) Visha - peeta Poisoning

(3) Sarpa-Damsha Snake bits

(4) Vrisehika Damsha Scorpion Bite

Some experience by practice reveals that Ayurveda can also be useful in emergency conditions and life threatening conditions. Some examples are cited below to justify that ayurveda can also be useful in emergency conditions.

\section{Case No. 1: Pralapaka - sannipat jwara:}

A patient suffering from Typhoid suffered from semi consciousness and also muttering delirium. My diagnosis was 'Pralapaka Jwara'.The following quath was given repeatedly every 3 hrs. \& his delirium subsided.
(1) Tagar (7) Aswagandha
(2)Pitta - Papada (8) Brahmi
(3)Amaltas (9) Daksha
(4)Musta (10) Chandana
(5)Katuki (11) Dashmoola
(6)Lamajjaka (12) Shankhapuspi

The kanslation is from Hariharprasad Pandya. Latin names from Dravyaguna by Yadavji T. Acharya. The result of this quath was very good; the delirium subsided; the patient had a 
sound sleep and the fever also came down to normal within 2 to 3 days.

\section{Case No.2: Dehydration}

Immediately treatment was started. The treatment was -

(1) Karpoor Rasa - 1 Pill 3 times a day

(2) Lemon juice + Honey + Water - Just like syrup was given for drinking. At a time not more than $1 / 4$ glass i.e. about 1 to $1 \frac{1 / 2}{2}$ of water should be taken. Shankh bhasma $250 \mathrm{mg}$ to be taken 3 to 4 times with lemon syrup.

Within 1 day the frequency of stool was controlled. Gradually the stool was formed and vomiting subsided. His diarrhea was controlled with 4 to 5 days.

Many more examples can be cited. The ancient physicians were treating such cases. But since last few years, this question has been raised (5).

\section{Traditional medicines (6)}

India is known for its traditional medicinal systems-Ayurveda, Siddha, and Unani.. Food is the major source for serving the nutritional needs, but with growing modernization some traditional methods are being given up (Table 1). Hence, the modern food habits are affecting the balanced nutrition (7).

Table 3 Impact of modern food concept in required nutrition.

\begin{tabular}{|c|c|c|c|}
\hline Nutrients & $\begin{array}{c}\text { Intake by } \\
\text { traditional } \\
\text { ways }\end{array}$ & $\begin{array}{c}\text { Intake by } \\
\text { modern ways }\end{array}$ & Effect on nutrient intake \\
\hline $\begin{array}{l}\text { Water soluble } \\
\text { vitamins } \\
\text { (vitamins B } \\
\text { and C) and } \\
\text { minerals }\end{array}$ & $\begin{array}{l}\text { Vegetables } \\
\text { used for } \\
\text { cooking } \\
\text { were/are fresh }\end{array}$ & $\begin{array}{l}\text { Freezing and } \\
\text { packaging of the } \\
\text { cut vegetables }\end{array}$ & $\begin{array}{l}\text { Loss of ascorbic acid, water soluble } \\
\text { vitamins, and minerals }\end{array}$ \\
\hline $\begin{array}{l}\text { Proteins, } \\
\text { minerals, and } \\
\text { vitamin B } \\
\text { complex }\end{array}$ & $\begin{array}{l}\text { Manual } \\
\text { processing of } \\
\text { cereals, without } \\
\text { polishing }\end{array}$ & $\begin{array}{l}\text { Milling and } \\
\text { polishing of } \\
\text { cereals }\end{array}$ & $\begin{array}{l}\text { Reduces protein, minerals, and } \\
\text { vitamin B complex }\end{array}$ \\
\hline $\begin{array}{l}\text { Calcium, iron, } \\
\text { thiamine, and } \\
\text { niacin }\end{array}$ & $\begin{array}{l}\text { Fresh grinding } \\
\text { at home }\end{array}$ & $\begin{array}{l}\text { Heavy milling } \\
\text { and poor storage } \\
\text { conditions }\end{array}$ & $\begin{array}{l}\text { Loss of calcium, iron, thiamin, and } \\
\text { niacin }\end{array}$ \\
\hline Iron & $\begin{array}{l}\text { Cooking in iron } \\
\text { pot }\end{array}$ & $\begin{array}{l}\text { Food generally } \\
\text { cooked in } \\
\text { cookware like } \\
\text { nonstick and } \\
\text { Teflon-coated } \\
\text { utensils }\end{array}$ & $\begin{array}{l}\text { The benefit of organic iron from the } \\
\text { conventional iron pot is not obtained } \\
\text { by using modern cookware }\end{array}$ \\
\hline Copper & $\begin{array}{l}\text { Storing of } \\
\text { water and } \\
\text { cooking use of } \\
\text { copper vessels }\end{array}$ & $\begin{array}{l}\text { Stainless steel } \\
\text { utensils and } \\
\text { plastic wares }\end{array}$ & $\begin{array}{l}\text { Copper required in minor amount } \\
\text { which is not gained from modern } \\
\text { utensils used today. Deficiency is } \\
\text { known to cause chronic diarrhea, } \\
\text { malabsorption problems, and reduce } \\
\text { immunity. Use of plastic containers is } \\
\text { also harmful }\end{array}$ \\
\hline
\end{tabular}

\section{Medicinal Plants Used in Alternative/} Traditional Medicines

India is the leading producer of medicinal plants. In India, around 20,000 medicinal plants have been recorded; however, traditional practitioners use only 7,000-7,500 plants for curing different diseases. The proportion of use of plants in the different 
Indian systems of medicine is Ayurveda 2000, Siddha 1300, Unani 1000, Homeopathy 800, Tibetan 500, Modern 200, and folk 4500. In India, around 25,000 effective plant-based formulations are used in traditional and folk medicine. More than 1.5 million practitioners are using the traditional medicinal system for health care in India. It is estimated that more than 7800 manufacturing units are involved in the production of natural health products and Table 4 Some common medicinal plants having nutraceutical potential and their primary use in traditional medicine (8).

\begin{tabular}{|c|c|c|}
\hline Plant name & Common name & Uses \\
\hline $\begin{array}{l}\text { Asparagus } \\
\text { racemosus Willd }\end{array}$ & Shatavari & $\begin{array}{l}\text { A potent Ayurvedic rejuvenative. It supplies many } \\
\text { female hormones and mostly recommended for } \\
\text { those women who have hysterectomies. It also } \\
\text { helps to maintain urinary tract and strengthens the } \\
\text { immune system and also purifies the blood. }\end{array}$ \\
\hline $\begin{array}{l}\text { Commiphora } \\
\text { mukul Engl. }\end{array}$ & Guggul & $\begin{array}{l}\text { A major ingredient in joint and immunocare and } \\
\text { regarded as a remedy in Ayurvedic medicine; it } \\
\text { increase white blood cell count to possess strong } \\
\text { immuno-modulating properties. It also protects } \\
\text { against the common cold as well as used in } \\
\text { various other conditions like lower cholesterol and } \\
\text { triglycerides, while maintaining the HDL to LDL } \\
\text { ratio. }\end{array}$ \\
\hline Cyperus scariosus Br. & Nagarmusta & $\begin{array}{l}\text { Useful in supporting healthy genitourinary system } \\
\text { and have hepatoprotective properties. }\end{array}$ \\
\hline Garcinia cambogia Dr & Garcinia & $\begin{array}{l}\text { Fruits contain biologically active compounds (-) } \\
\text { hydroxycitric acid, which is known to inhibit the } \\
\text { synthesis of lipids and fatty acids. HCA inhibits } \\
\text { the enzyme ATP-citrate lyase that leads to reduce } \\
\text { production of acetyl CoA, which is a key } \\
\text { substance in fat and carbohydrate metabolism. } \\
\text { Therefore, formation of LDL and triglycerides is } \\
\text { very low. It also suppresses appetite by promoting } \\
\text { synthesis of glycogen. That way the brain gets } \\
\text { signals of fullness and satisfaction sooner. } \\
\text { Garcinia contains significant amounts of vitamin } \\
\text { C and used as a heart tonic. }\end{array}$ \\
\hline Glycyrrhiza glabra L. & $\begin{array}{l}\text { Yashtimadhu, } \\
\text { Licorice }\end{array}$ & $\begin{array}{l}\text { It is a versatile medicine in India and China, for } \\
\text { gastrointestinal health. It is a mild laxative, } \\
\text { soothes and tones the mucous membranes, and } \\
\text { relieves muscle spasms. It is an antioxidant, } \\
\text { cancer protecting, botanical boosting, and certain } \\
\text { immune functions such as interferon production. } \\
\text { Its mode of action is as an antimutagen, } \\
\text { preventing damage to genetic material that can } \\
\text { eventually result in cancer. }\end{array}$ \\
\hline $\begin{array}{l}\text { Gymnema sylvestre R. } \\
\text { Br. }\end{array}$ & Gurmarar & $\begin{array}{l}\text { Its Sanskrit name means literally "sugar } \\
\text { destroyer," has a glycolytic action, and reduces the }\end{array}$ \\
\hline
\end{tabular}

traditional plant-based formulations in India, which requires more than 2000 tons of medicinal plant raw material annually. More than 1500 herbals are sold as dietary supplements or ethnic traditional medicines.

Some common medicinal plants having nutraceutical potential and their primary use in traditional medicine [6-26] are being given in Table 2(8). 


\begin{tabular}{|c|c|c|}
\hline & & $\begin{array}{l}\text { strength of a glucose solution. It has been used in } \\
\text { Ayurveda to regulate sugar metabolism for several } \\
\text { centuries. It increases insulin production, } \\
\text { regeneration of pancreas cells, and the site of } \\
\text { insulin production. Another property is abolishing } \\
\text { the taste of sugar, so that Gurmarar has been } \\
\text { effective to suppress and neutralize the craving for } \\
\text { sweets. }\end{array}$ \\
\hline Melia azadirachta L. & Nimba, Neem & $\begin{array}{l}\text { It has strong health alleviating activity, used as a } \\
\text { tonic and astringent that promotes healing. The } \\
\text { extract has antispasmodic action. Its usage in } \\
\text { Ayurvedic medicine for thousands of years has } \\
\text { proved its detoxifying properties. It has shown } \\
\text { most beneficial effects for the circulatory, } \\
\text { digestive, respiratory, and urinary systems. }\end{array}$ \\
\hline $\begin{array}{l}\text { Momordica } \\
\text { charantia L. }\end{array}$ & $\begin{array}{l}\text { Karela, Bitter } \\
\text { melon }\end{array}$ & $\begin{array}{l}\text { Karela has been widely used in Ayurvedic } \\
\text { medicine. It contains Gurmarin, a polypeptide } \\
\text { considered to be similar to bovine insulin, and has } \\
\text { a strong sugar regulating effect by suppressing the } \\
\text { neural responses to sweet taste stimuli. }\end{array}$ \\
\hline $\begin{array}{l}\text { Moringa } \\
\text { pterygosperma Gaertn }\end{array}$ & $\begin{array}{l}\text { Shigru, } \\
\text { Horseradish tree }\end{array}$ & $\begin{array}{l}\text { Shigru contains physiologically active principles } \\
\text { that is effective in a broad range of health needs. It } \\
\text { contains "Pterygospermin," an antibiotic-like } \\
\text { substance. }\end{array}$ \\
\hline $\begin{array}{l}\text { Mucuna } \\
\text { pruriens Baker }\end{array}$ & $\begin{array}{l}\text { Kiwanch, } \\
\text { Kapikachchhu, } \\
\text { Cow-itch plant }\end{array}$ & $\begin{array}{l}\text { It is a good natural source of L. dopa. In the } \\
\text { Ayurvedic system it is reported as an effective } \\
\text { tonic for nervous system. Studies have } \\
\text { demonstrated its usefulness maintaining optimum } \\
\text { performance of the nervous system. }\end{array}$ \\
\hline $\begin{array}{l}\text { Nardostachys } \\
\text { jatamansi DC. }\end{array}$ & $\begin{array}{l}\text { Jatamansi, Musk } \\
\text { root }\end{array}$ & $\begin{array}{l}\text { Jatamansi is a relaxing plant, effectiveness for } \\
\text { mental health. It is used in various Ayurvedic } \\
\text { formulations as a potent ingredient. It has been } \\
\text { shown effective in maintaining a restful sleep and } \\
\text { with many menopausal symptoms. }\end{array}$ \\
\hline Piper longum L. & $\begin{array}{l}\text { Pippali, Indian } \\
\text { Long Pepper }\end{array}$ & $\begin{array}{l}\text { Pippali is a powerful stimulant for both the } \\
\text { digestive and the respiratory systems and has a } \\
\text { rejuvenating effect on lungs. It plays an important } \\
\text { role in release of metabolic heat energy. This } \\
\text { effect is the result of increased thyroid hormone } \\
\text { level in the body. Pippali a typical Ayurvedic } \\
\text { complementary component whose benefit is to } \\
\text { increase the bioavailability and enhance } \\
\text { absorption of the other active ingredients. }\end{array}$ \\
\hline Piper nigrum $\mathrm{L}$. & $\begin{array}{l}\text { Maricha, Black } \\
\text { pepper }\end{array}$ & $\begin{array}{l}\text { The black pepper is one of the most important } \\
\text { spices which is widely used to amplify the body's } \\
\text { ability to absorb nutrients contained in the food } \\
\text { and aid the digestive process. }\end{array}$ \\
\hline Bergenia ligulata Wall & Pasanavheda & $\begin{array}{l}\text { It has the unique property like diuretic action with } \\
\text { optimum urinary tract health. This important drug } \\
\text { supports bladder by acting on the crystalloid- } \\
\text { colloid balance and keeping calcium salts in }\end{array}$ \\
\hline
\end{tabular}




\begin{tabular}{|c|c|c|}
\hline & & solution. \\
\hline $\begin{array}{l}\text { Terminalia } \\
\text { chebula Retz. }\end{array}$ & Haritaki & $\begin{array}{l}\text { Haritaki is a safe and effective purgative, } \\
\text { expectorant, and tonic. It is an important } \\
\text { ingredient of the classical Ayurvedic formulation } \\
\text { "Triphala" which has a combination of three } \\
\text { fruits. Tiphalpha is an important Ayurvedic } \\
\text { medicine, which promotes health through } \\
\text { successive steps of purification and detoxification. } \\
\text { It is known to have strong antimutagenic activity, } \\
\text { because of its very rich content vitamin C. }\end{array}$ \\
\hline $\begin{array}{l}\text { Tinospora } \\
\text { cordifolia Miers }\end{array}$ & Guduchi & $\begin{array}{l}\text { Guduchi is a rich source of natural vitamin } C \text { and } \\
\text { effective in inhibiting the growth of bacteria and } \\
\text { in building up the immune resistance and has } \\
\text { immune-boosting ability. Use of this plant } \\
\text { increases white blood cells the killing ability of } \\
\text { macrophages, the immune cells responsible for } \\
\text { fighting invaders. }\end{array}$ \\
\hline $\begin{array}{l}\text { Withania } \\
\text { somnifera (L.) Dunal }\end{array}$ & Ashwagandha & $\begin{array}{l}\text { In Ayurvedic medicines Ashwagandha holds a } \\
\text { place similar to Ginseng in traditional Chinese } \\
\text { medicinal therapies. It is also called the "Indian } \\
\text { Ginseng." It has been used for thousands of years } \\
\text { as a popular remedy in Ayurvedic systems for } \\
\text { many conditions. It is one of the best health tonics } \\
\text { and restorative agents that have been used to treat } \\
\text { general debility. }\end{array}$ \\
\hline $\begin{array}{l}\text { Zingiber } \\
\text { officinale Rosc }\end{array}$ & Sunthi, Ginger & $\begin{array}{l}\text { Ginger is considered an adjuvant in many } \\
\text { Ayurvedic formulas in which it enhances } \\
\text { absorption and prevents gastrointestinal side } \\
\text { effects. It is a very common spice which is used in } \\
\text { Ayurvedic medicine to improve digestion and to } \\
\text { prevent nausea. These properties help bowel } \\
\text { movements and relax the muscles which control } \\
\text { the digestive system. }\end{array}$ \\
\hline
\end{tabular}

Expanding Complementary and Alternative (CAM) Approaches

Among wealthier populations in both developed and developing countries, complementary and alternative practices are popular although proof of their safety and effectiveness is modest. The National Center for Complementary and Alternative Medicine has been inaugurated as the United States Federal Government's lead agency for scientific research in this arena of medicine. Its mission is to explore complementary and alternative healing practices in the context of rigorous science, support sophisticated research, train researchers, disseminate information to the public on the modalities that work, and explain the scientific rationale underlying discoveries. The center is committed to explore and fund all such therapies for which there is sufficient preliminary data, compelling public health need and ethical justifications.

Nowadays people seek CAM techniques because they believe the side effects will be lower. In both developed and developing countries, users of complementary methods also commonly seek conventional care .

Table 3 enlists some important Ayurvedic herbal formulations (9). 
Table 5 Some important herbal formulations frequently used in traditional Ayurvedic system in India.

\begin{tabular}{|c|c|c|}
\hline Disease & Formulation's ingredients/ratio & Dose/method of use \\
\hline Anemia & $\begin{array}{l}\text { Asparagus racemosus (roots) } 20 \% \\
\text { Withania somnifera (roots) } 20 \% \\
\text { Phyllanthus emblica (fruits) } 15 \% \\
\text { P. amarus (leaves) } 10 \% \\
\text { Tephrosia purpurea (leaves) } 10 \% \\
\text { Plumbago zeylanica (roots) } 5 \% \\
\text { Glycyrrhiza glabra (roots) } 15 \% \\
\text { Piper longum (fruits) 5\% }\end{array}$ & $\begin{array}{l}4 \mathrm{gm} \text { of powder is given to the } \\
\text { patient, twice daily with water }\end{array}$ \\
\hline Asthma/bronchitis & $\begin{array}{l}\text { Solanum xanthocarpum (whole } \\
\text { plant) } 25 \% \\
\text { Piper longum (fruits) } 10 \% \\
\text { Adhatoda vasica (leaves) } 25 \% \\
\text { Zingiber officinale (roots) } 10 \% \\
\text { Curcuma zedoaria (roots) } 10 \% \\
\text { Ocimum sanctum (leaves) } 10 \% \\
\text { Phyllanthus emblica (fruits) } 10 \%\end{array}$ & $\begin{array}{l}4 \mathrm{gm} \text { (one teaspoonful) of mixed } \\
\text { powder given to the patient, twice } \\
\text { a day (morning and at bedtime) } \\
\text { with water }\end{array}$ \\
\hline Arthritis & $\begin{array}{l}\text { Piper longum (fruits) } 10 \% \\
\text { S. xanthocarpum (whole plant) } 15 \% \\
\text { Withania somnifera (roots) } 10 \% \\
\text { Terminalia chebula (fruits) } 10 \% \\
\text { T. bellerica (fruits) } 10 \% \\
\text { Curcuma zedoaria (roots) } 15 \% \\
\text { Phyllanthus emblica (fruits) } 15 \% \\
\text { Ricinus communis (roots) } 15 \%\end{array}$ & $\begin{array}{l}4 \text { gm of mixed powder should be } \\
\text { given to the patient, twice daily } \\
\text { (morning and evening, one hour } \\
\text { before meals) with ginger juice for } \\
\text { rheumatic problems }\end{array}$ \\
\hline Blood circulation & $\begin{array}{l}\text { Zingiber officinale (roots) } 20 \% \\
\text { Piper longum (roots) } 10 \% \\
\text { Withania somnifera (roots) } 10 \% \\
\text { Phyllanthus emblica (fruits) } 10 \% \\
\text { Curcuma longa (roots) } 10 \% \\
\text { Terminalia bellerica (fruits) } 10 \% \\
\text { T. chebula (fruits) } 10 \% \\
\text { Ocimum sanctum (leaves) } 10 \% \\
\text { Tephrosia purpurea (leaves) } 10 \%\end{array}$ & $\begin{array}{l}4 \mathrm{gm} \text { of mixed powder is given to } \\
\text { the patient, twice daily with water }\end{array}$ \\
\hline Cancer & $\begin{array}{l}\text { Azadirachta indica (bark) } 20 \% \\
\text { Bauhinia variegata (bark) } 15 \% \\
\text { Crataeva nurvala (bark) } 15 \% \\
\text { Terminalia chebula (fruits) } 15 \% \\
\text { T. bellerica (fruits) } 10 \% \\
\text { Holarrhena antidysenterica (bark) } \\
10 \% \\
\text { Tinospora cordifolia (stems) } 15 \%\end{array}$ & $\begin{array}{l}4 \mathrm{gm} \text { of mixed powder should be } \\
\text { given to the patient, twice a day } \\
\text { (morning and night) with } \\
\text { lukewarm honey for cancer cure }\end{array}$ \\
\hline
\end{tabular}




\begin{tabular}{|c|c|c|}
\hline $\begin{array}{l}\text { Chronic } \\
\text { constipation }\end{array}$ & $\begin{array}{l}\text { Holarrhena antidysenterica (bark) } \\
10 \% \\
\text { Plumbago ovata (husk) } 20 \% \\
\text { Terminalia bellerica (fruits) } 10 \% \\
\text { T. chebula (fruits) } 15 \% \\
\text { Phyllanthus emblica (fruits) } 15 \% \\
\text { Cassia angustifolia (leaves) } 20 \% \\
\text { Glycyrrhiza glabra (roots) } 10 \%\end{array}$ & $\begin{array}{l}4 \text { gm of mixed powder is given to } \\
\text { the patient, at night before going to } \\
\text { bed, with water }\end{array}$ \\
\hline Chronic fever & $\begin{array}{l}\text { Tinospora cordifolia (stems) } 15 \% \\
\text { Ocimum sanctum (leaves) } 15 \% \\
\text { Adhatoda vasica (leaves) } 15 \% \\
\text { Azadirachta indica (leaves) } 15 \% \\
\text { Holarrhena antidysenterica (bark) } \\
10 \% \\
\text { Piper longum (fruits) } 10 \% \\
\text { Zingiber officinale (roots) } 10 \% \\
\text { Terminalia bellerica (fruits) } 10 \%\end{array}$ & $\begin{array}{l}4 \mathrm{gm} \text { of mixed powder is given to } \\
\text { the patient, twice daily before } \\
\text { meals with water. }\end{array}$ \\
\hline Cough & $\begin{array}{l}\text { Phyllanthus emblica (fruits) } 25 \% \\
\text { Adhatoda vasica (leaves) } 20 \% \\
\text { Ocimum sanctum (leaves) } 10 \% \\
\text { Piper longum (fruits) } 10 \% \\
\text { Zingiber officinale (roots) } 10 \% \\
\text { Glycyrrhiza glabra (roots) } 15 \% \\
\text { Solanum xanthocarpum (whole } \\
\text { plant) } 10 \%\end{array}$ & $\begin{array}{l}3 \text { gm of mixed powder should be } \\
\text { given to the patient twice daily } \\
\text { (morning and at night before going } \\
\text { to bed) with lukewarm mixed with } \\
\text { honey to cure cold }\end{array}$ \\
\hline Cysts & $\begin{array}{l}\text { Terminalia chebula (fruits) } 20 \% \\
\text { Azadirachta indica (bark) } 20 \% \\
\text { Holarrhena antidysenterica (bark) } \\
10 \% \text {, Terminalia bellerica (fruits) } \\
10 \% \\
\text { Withania somnifera (roots) } 20 \% \\
\text { Tinospora cordifolia (stems) } 20 \%\end{array}$ & $\begin{array}{l}4 \mathrm{gm} \text { of mixed (one teaspoonful) } \\
\text { powder is given to the patient, } \\
\text { twice a day (morning and evening) } \\
\text { with water }\end{array}$ \\
\hline Dental diseases & $\begin{array}{l}\text { Azadirachta indica (leaves) } 15 \% \\
\text { A. arabia (bark) } 15 \% \\
\text { Areca catechu (bark) } 15 \% \\
\text { Achyranthes aspera (leaves) } 10 \% \\
\text { Ficus benghalensis (bark) } 15 \% \\
\text { Quercus infectoria (fruits) } 15 \% \\
\text { Symplocos racemosa (bark) } 15 \%\end{array}$ & $\begin{array}{l}\text { The powder is applied to the gums } \\
\text { and teeth, two times a day. } \\
\text { Additionally a gargle of the } \\
\text { decoction ( } 3 \text { gm of powder mixed } \\
\text { in } 150 \mathrm{~mL} \text { of water) }\end{array}$ \\
\hline Diarrhoea & $\begin{array}{l}\text { Holarrhena antidysenterica (bark) } \\
25 \% \\
\text { Aegle marmelos (fruits) } 25 \% \\
\text { Zingiber officinale (roots) } 10 \% \\
\text { Terminalia chebula (fruits) } 10 \% \\
\text { Cyperus rotundus (roots) } 10 \% \\
\text { Syzygium cumini (seeds) } 10 \% \\
\text { Phyllanthus emblica (fruits) } 10 \%\end{array}$ & $\begin{array}{l}3 \text { gm of mixed powder is given to } \\
\text { the patient, three times a day, with } \\
\text { curd for dysentery and diarrhoea }\end{array}$ \\
\hline $\begin{array}{l}\text { Dislocation of } \\
\text { bones }\end{array}$ & $\begin{array}{l}\text { Asparagus racemosus (roots) } 15 \% \\
\text { Withania somnifera (roots) } 15 \% \\
\text { Azadirachta arabica (bark) } 20 \% \\
\text { Terminalia arjuna (bark) } 20 \%\end{array}$ & $\begin{array}{l}3 \text { gm of mixed powder is given to } \\
\text { the patient, twice a day with water } \\
\text { for dislocation of bones and } \\
\text { fractures }\end{array}$ \\
\hline
\end{tabular}




\begin{tabular}{|c|c|c|}
\hline & $\begin{array}{l}\text { T. chebula (fruits) } 10 \% \\
\text { T. bellerica (fruits) } 10 \% \\
\text { Phyllanthus emblica (fruits) } 10 \%\end{array}$ & \\
\hline Diabetes & $\begin{array}{l}\text { Gymnema sylvestre (leaves) } 30 \% \\
\text { Tinospora cordifolia (stems) } 15 \% \\
\text { Azadirachta indica (leaves) } 10 \% \\
\text { Phyllanthus emblica (fruits) } 20 \% \\
\text { Curcuma longa (roots) } 10 \% \\
\text { Aegle marmelos (leaves) } 15 \%\end{array}$ & $\begin{array}{l}4 \mathrm{gm} \text { of mixed powder should be } \\
\text { given to the patient, twice a day } \\
\text { with water }\end{array}$ \\
\hline Fistula & $\begin{array}{l}\text { Glycyrrhiza glabra (roots) } 20 \% \\
\text { Terminalia chebula (fruits) } 20 \% \\
\text { T. bellerica (fruits) } 15 \% \\
\text { Tinospora cordifolia (stems) } 15 \% \\
\text { Azadirachta indica (leaves) } 15 \% \\
\text { Withania somnifera (roots) } 15 \%\end{array}$ & $\begin{array}{l}3 \mathrm{gm} \text { of mixed powder should be } \\
\text { given to the patient, twice daily } \\
\text { with water to treat fistula }\end{array}$ \\
\hline Female sterility & $\begin{array}{l}\text { Asparagus racemosus (roots) } 20 \% \\
\text { Withania somnifera (roots) } 20 \% \\
\text { Glycyrrhiza glabra (roots) } 20 \% \\
\text { Phyllanthus emblica (fruits) } 10 \% \\
\text { Ficus glomerata (bark) } 10 \% \\
\text { F. religiosa (bark) } 10 \%\end{array}$ & $\begin{array}{l}3 \mathrm{gm} \text { of mixed powder is given to } \\
\text { the patient twice daily, half an hour } \\
\text { before meals with milk }\end{array}$ \\
\hline $\begin{array}{l}\text { General health } \\
\text { tonic }\end{array}$ & $\begin{array}{l}\text { Withania somnifera (roots) } 20 \% \\
\text { Asparagus racemosus (roots) } 10 \% \\
\text { Glycyrrhiza glabra (roots) } 10 \% \\
\text { Tribulus terrestris (fruits) } 10 \% \\
\text { Phyllanthus emblica (fruits) } 15 \% \\
\text { Terminalia arjuna (bark) } 15 \% \\
\text { Centella asiatica (leaves) } 10 \%\end{array}$ & $\begin{array}{l}4 \mathrm{gm} \text { of powder is given to the } \\
\text { patient, twice daily (morning and } \\
\text { evening) with milk }\end{array}$ \\
\hline Gastritis & $\begin{array}{l}\text { Zingiber officinale (roots) } 10 \% \\
\text { Piper longum (fruits) } 10 \% \\
\text { Mentha piperita (leaves) } 10 \% \\
\text { Terminalia chebula (fruits) } 15 \% \\
\text { T. bellerica (fruits) } 15 \% \\
\text { Phyllanthus emblica (fruits) } 15 \% \\
\text { Plumbago zeylanica (roots) } 10 \% \\
\text { Tinospora cordifolia (stems) } 15 \%\end{array}$ & $\begin{array}{l}4 \text { gm of (one teaspoonful) mixed } \\
\text { powder is given to the patient } \\
\text { twice daily, half an hour before } \\
\text { meals with water }\end{array}$ \\
\hline Hair problems & $\begin{array}{l}\text { Eclipta alba (leaves) } 15 \% \\
\text { Centella asiatica (leaves) } 15 \% \\
\text { Terminalia chebula (fruits) } 10 \% \\
\text { T. bellerica (fruits) } 10 \% \\
\text { Phyllanthus emblica (fruits) } 15 \% \\
\text { Glycyrrhiza glabra (roots) } 15 \% \\
\text { Tinospora cordifolia (stems) } 10 \% \\
\text { Tribulus terrestris (fruits) } 10 \%\end{array}$ & $\begin{array}{l}4 \mathrm{gm} \text { of mixed powder is given to } \\
\text { the patient, twice a daily with } \\
\text { honey }\end{array}$ \\
\hline $\begin{array}{l}\text { High blood } \\
\text { pressure }\end{array}$ & $\begin{array}{l}\text { Terminalia arjuna (bark) } 35 \% \\
\text { T. chebula (fruits) } 15 \% \\
\text { Asparagus racemosus (roots) } 15 \% \\
\text { Zingiber officinale (roots) } 10 \% \\
\text { Withania somnifera (roots) } 25 \%\end{array}$ & $\begin{array}{l}4 \mathrm{gm} \text { of powder is given to the } \\
\text { patient, twice a day (morning and } \\
\text { night) with honey }\end{array}$ \\
\hline Heart tonic & $\begin{array}{l}\text { Withania somnifera (roots) } 10 \% \\
\text { Terminalia arjuna (bark) } 30 \%\end{array}$ & $\begin{array}{l}3 \text { gm of mixed powder is given to } \\
\text { the patient, twice a day with water }\end{array}$ \\
\hline
\end{tabular}




\begin{tabular}{|c|c|c|}
\hline & $\begin{array}{l}\text { T. bellerica (fruits) } 10 \% \\
\text { T. chebula (fruits) } 10 \% \\
\text { Cyperus rotundus (roots) } 10 \% \\
\text { Phyllanthus emblica (fruits) } 10 \% \\
\text { Ocimum sanctum (leaves) } 10 \%\end{array}$ & \\
\hline Intestinal worms & $\begin{array}{l}\text { Holarrhena antidysenterica (bark) } \\
10 \% \\
\text { Mentha piperita (leaves) } 10 \% \\
\text { Tinospora cordifolia (stems) } 20 \% \\
\text { Butea monosperma (seeds) } 20 \% \\
\text { Azadirachta indica (leaves) } 10 \% \\
\text { Phyllanthus emblica (fruits) } 20 \% \\
\text { Tribulus terrestris (fruits) } 10 \%\end{array}$ & $\begin{array}{l}3 \mathrm{gm} \text { of mixed powder is given to } \\
\text { the patient, twice daily (morning } \\
\text { and night) with water }\end{array}$ \\
\hline Epilepsy & $\begin{array}{l}\text { Centella asiatica (leaves) } 30 \% \\
\text { Withania somnifera (roots) } 20 \% \\
\text { Tribulus terrestris (fruits) } 15 \% \\
\text { Piper longum (roots) } 10 \% \\
\text { Achyranthes aspera (leaves) } 15 \% \\
\text { Plumbago zeylanica (roots) } 10 \%\end{array}$ & $\begin{array}{l}3 \text { gm mixed powder is given to the } \\
\text { patient, twice daily (morning and } \\
\text { evening) with fruit juice to treat } \\
\text { Hysteria }\end{array}$ \\
\hline Leucorrhoea & $\begin{array}{l}\text { Symplocos racemosa (bark) } 35 \% \\
\text { Asparagus racemosus (roots) } 15 \% \\
\text { Adhatoda vasica (leaves) } 10 \% \\
\text { Aegle marmelos (fruits) } 10 \% \\
\text { Phyllanthus emblica (fruits) } 10 \% \\
\text { Azadirachta indica (bark) } 10 \%\end{array}$ & $\begin{array}{l}3 \mathrm{gm} \text { of mixed powder is given to } \\
\text { the patient, twice daily with water }\end{array}$ \\
\hline Leucoderma & $\begin{array}{l}\text { Psoralea corylifolia (seeds) } 20 \% \\
\text { Terminalia chebula (fruits) } 10 \% \\
\text { Phyllanthus emblica (fruits) } 20 \% \\
\text { Azadirachta indica (bark) } 20 \% \\
\text { Areca catechu (bark) } 10 \% \\
\text { Tinospora cordifolia (stems) } 10 \% \\
\text { Eclipta alba (leaves) } 10 \%\end{array}$ & $\begin{array}{l}3 \mathrm{gm} \text { of mixed powder should be } \\
\text { given to the patient, twice a day } \\
\text { before meals with water }\end{array}$ \\
\hline Liver tonic & $\begin{array}{l}\text { Holarrhena antidysenterica (bark) } \\
10 \% \\
\text { Eclipta alba (leaves) } 20 \% \\
\text { Tephrosia purpurea (leaves) } 20 \% \\
\text { Tinospora cordifolia (stems) } 10 \% \\
\text { Azadirachta indica (bark) } 10 \% \\
\text { Phyllanthus amarus (whole plant) } \\
20 \% \\
\text { Plumbago zeylanica (roots) } 10 \%\end{array}$ & $\begin{array}{l}4 \mathrm{gm} \text { of mixed powder is given to } \\
\text { the patient twice daily, half an hour } \\
\text { before meals with water }\end{array}$ \\
\hline Lack of appetite & $\begin{array}{l}\text { Zingiber officinale (roots) } 10 \% \\
\text { Piper longum (fruits) } 10 \%, \\
\text { Phyllanthus emblica (fruits) } 30 \% \\
\text { Terminalia chebula (fruits) } 15 \% \\
\text { Tinospora cordifolia (stems) } 15 \% \\
\text { Cassia angustifolia (leaves) } 10 \% \\
\text { Mentha piperita (leaves) } 10 \%\end{array}$ & $\begin{array}{l}4 \mathrm{gm} \text { of mixed powder is given to } \\
\text { the patient, two times a day after } \\
\text { meals with water for indigestion }\end{array}$ \\
\hline Male sterility & $\begin{array}{l}\text { Withania somnifera (roots) } 15 \% \\
\text { Mucuna pruriens (seeds) } 25 \% \\
\text { Tribulus terrestris (fruits) } 20 \%\end{array}$ & $\begin{array}{l}4 \mathrm{gm} \text { of mixed powder is given to } \\
\text { the patient, twice a day with honey }\end{array}$ \\
\hline
\end{tabular}




\begin{tabular}{|c|c|c|}
\hline & $\begin{array}{l}\text { Glycyrrhiza glabra (roots) } 10 \% \\
\text { Terminalia arjuna (bark) } 10 \% \\
\text { Phyllanthus emblica (fruits) } 10 \% \\
\text { Zingiber officinale (roots) } 5 \% \\
\text { Piper longum (fruits) 5\% }\end{array}$ & \\
\hline Migraine & $\begin{array}{l}\text { Curcuma longa (roots) } 15 \% \\
\text { Glycyrrhiza glabra (roots) } 15 \% \\
\text { Azadirachta indica (bark) 15\% } \\
\text { Tinospora cordifolia (stems) } 15 \% \\
\text { Terminalia chebula (fruits) } 10 \% \\
\text { Ocimum sanctum (leaves) } 15 \% \\
\text { Eclipta alba (leaves) } 15 \%\end{array}$ & $\begin{array}{l}4 \mathrm{gm} \text { of mixed powder is given to } \\
\text { the patient, twice a day with honey }\end{array}$ \\
\hline Obesity & $\begin{array}{l}\text { Terminalia chebula (fruits) } 15 \% \\
\text { Terminalia bellerica (fruits) } 15 \% \\
\text { Phyllanthus emblica (fruits) } 10 \% \\
\text { Crataeva nurvala (bark) } 25 \% \\
\text { Tribulus terrestris (fruits) } 25 \% \\
\text { Zingiber officinale (roots) } 10 \%\end{array}$ & $\begin{array}{l}4 \mathrm{gm} \text { of powder is given to the } \\
\text { patient, twice a day with warm } \\
\text { water }\end{array}$ \\
\hline Paralysis & $\begin{array}{l}\text { Curcuma zedoaria (roots) } 20 \% \\
\text { Withania somnifera (roots) } 20 \% \\
\text { Tribulus terrestris (fruits) } 20 \% \\
\text { Zingiber officinale (roots) } 20 \% \\
\text { Piper longum (fruits) 5\% } \\
\text { Crataeva nurvala (leaves) } 10 \% \\
\text { Plumbago zeylanica (roots) } 5 \%\end{array}$ & $\begin{array}{l}3 \mathrm{gm} \text { of mixed powder is given to } \\
\text { the patient, three times a day with } \\
\text { honey }\end{array}$ \\
\hline $\begin{array}{l}\text { Prostate } \\
\text { enlargement }\end{array}$ & $\begin{array}{l}\text { Tinospora cordifolia (stems) } 15 \% \\
\text { Tribulus terrestris (fruits) } 15 \% \\
\text { Phyllanthus emblica (fruits) } 15 \% \\
\text { Zingiber officinale (roots) } 10 \% \\
\text { Butea monosperma (seeds) } 10 \% \\
\text { Adhatoda vasica (leaves) } 5 \% \\
\text { Terminalia chebula (fruits) } 10 \% \\
\text { T. bellerica (fruits) } 10 \% \\
\text { Glycyrrhiza glabra (roots) } 10 \%\end{array}$ & $\begin{array}{l}4 \text { gm of mixed powder is given to } \\
\text { the patient twice a day, morning } \\
\text { and evening before meals with } \\
\text { water }\end{array}$ \\
\hline Piles & $\begin{array}{l}\text { Eclipta alba (leaves) } 35 \% \\
\text { Terminalia chebula (fruits) } 15 \% \\
\text { Terminalia bellerica (fruits) } 10 \% \\
\text { Phyllanthus emblica (fruits) } 10 \% \\
\text { Adhatoda vasica (leaves) } 10 \% \\
\text { Plumbago zeylanica (roots) } 5 \% \\
\text { Piper longum (fruits) 5\% } \\
\text { Aegle marmelos (fruits) } 10 \%\end{array}$ & $\begin{array}{l}4 \mathrm{gm} \text { of mixed powder is given to } \\
\text { the patient, twice daily (morning } \\
\text { and at bedtime) with water }\end{array}$ \\
\hline Sleeplessness & $\begin{array}{l}\text { Withania somnifera (roots) 20\% } \\
\text { Centella asiatica (leaves) } 30 \% \\
\text { Piper longum (roots) } 20 \% \\
\text { Glycyrrhiza glabra (roots) } 10 \% \\
\text { Terminalia bellerica (fruits) } 10 \%\end{array}$ & $\begin{array}{l}3 \text { gm mixed powder is given to the } \\
\text { patient, at night before going to } \\
\text { bed, with milk }\end{array}$ \\
\hline Skin diseases & $\begin{array}{l}\text { Cyperus rotundus (roots) } 10 \% \\
\text { Tinospora cordifolia (stems) } 20 \% \\
\text { Azadirachta indica (bark) } 20 \% \\
\text { Terminalia chebula (fruits) } 10 \%\end{array}$ & $\begin{array}{l}3 \text { gm of powder is given to the } \\
\text { patient, twice a day before meals } \\
\text { with water to cure allergy } \\
\text { problems }\end{array}$ \\
\hline
\end{tabular}




\begin{tabular}{|c|c|c|}
\hline & $\begin{array}{l}\text { T. bellerica (fruits) } 10 \% \\
\text { Curcuma longa (roots) } 10 \% \\
\text { Phyllanthus emblica (fruits) } 10 \% \\
\text { Centella asiatica (leaves) } 10 \%\end{array}$ & \\
\hline Sexual debility & $\begin{array}{l}\text { Withania somnifera (roots) } 10 \% \\
\text { Mucuna pruriens (seeds) } 20 \% \\
\text { Asparagus racemosus (roots) } 10 \% \\
\text { Sida cordifolia (seeds) } 10 \% \\
\text { Tribulus terrestris (fruits) } 20 \% \\
\text { Glycyrrhiza glabra (roots) } 10 \%\end{array}$ & $\begin{array}{l}\text { About } 4 \mathrm{gm} \text { of mixed powder } \\
\text { should be given to the patient, } \\
\text { twice daily (morning and at night } \\
\text { before going to bed) with milk }\end{array}$ \\
\hline Throat diseases & $\begin{array}{l}\text { Glycyrrhiza glabra (roots) } 30 \% \\
\text { Terminalia chebula (fruits) } 10 \% \\
\text { T. bellerica (fruits) } 10 \% \\
\text { Solanum xanthocarpum (whole } \\
\text { plant) } 20 \% \\
\text { Piper longum (fruits) } 10 \% \\
\text { Sida cordifolia (roots) } 10 \% \\
\text { Phyllanthus emblica (fruits) } 10 \%\end{array}$ & $\begin{array}{l}4 \mathrm{gm} \text { of mixed powder is given to } \\
\text { the patient twice daily, morning } \\
\text { and at bedtime with honey }\end{array}$ \\
\hline Thyroid problems & $\begin{array}{l}\text { Crataeva nurvala (bark) } 20 \% \\
\text { Bauhinia variegata (bark) } 20 \% \\
\text { Sida cordifolia (leaves) } 15 \% \\
\text { Terminalia chebula (fruits) } 10 \% \\
\text { T. bellerica (fruits) } 10 \% \\
\text { Glycyrrhiza glabra (roots) } 15 \% \\
\text { Zingiber officinale (roots) } 10 \%\end{array}$ & $\begin{array}{l}3 \mathrm{gm} \text { of mixed powder is given to } \\
\text { the patient, twice daily with } \\
\text { lukewarm water }\end{array}$ \\
\hline Urinary tract & $\begin{array}{l}\text { Tribulus terrestris (fruits) } 25 \% \\
\text { Zingiber officinale (roots) } 10 \% \\
\text { Solanum xanthocarpum (whole } \\
\text { plant) } 10 \% \\
\text { Crataeva nurvala (bark) } 25 \% \\
\text { Tinospora cordifolia (stems) } 10 \% \\
\text { Asparagus racemosus (roots) } 10 \% \\
\text { Tephrosia purpurea (leaves) } 10 \%\end{array}$ & $\begin{array}{l}4 \mathrm{gm} \text { of mixed powder is given to } \\
\text { the patient, twice a day with water }\end{array}$ \\
\hline
\end{tabular}

\section{Nutraceuticals an Evolving Alternative Approach}

The requirement of external intervention, that can supplement diet to help prevent nutritionrelated disorders and promote wellness over treatment of various diseases, has become a necessity, and such products are known as nutraceuticals. Nutraceuticals, an emerging concept, can be broadly categorized as products which are extracted from natural sources (nature-like) or manufactured synthetically (man-made), which supplement the diet to provide nutrition over and above regular food and help prevent nutrition-related disorders. Nutraceuticals, foods or food components that help in prevention or treatment of disease, are made from herbal/botanical raw materials.
The nutraceutical industry is rapidly growing (7\%-12\% per year). With extensive anecdotal data on exciting health results, nutraceuticals promise significant contributions to disease prevention. The global nutraceuticals market is estimated at 117 billion US dollar of which India's share is a meager $0.9 \%$. United States and Japan are key markets for nutraceutical consumption. Indian nutraceuticals market is about 1 billion USD which is increasing day by day. Globally, this market is expected to reach 177 billion USD in 2013. The dietary supplements category is expected to be the fastest growing product category globally (10).

\section{Herbal Medicines in Dietary Supplements}

Dietary supplements and herbal remedies are popular complementary or alternative products 
for people. These are the supplements that are intended to supplement the diet and contain one or more dietary ingredients (including vitamins, minerals, herbs or other botanicals, amino acids, and other substances) or their constituents.

These botanicals are sold in many forms as fresh or dried products, liquid or solid extracts, tablets, capsules, powders, tea bags, and so forth. For example, fresh ginger root is often used in various food stores; dried ginger root is sold packaged in tea bags, capsules, or tablets, and liquid preparations made from ginger root are also sold in the market. A particular group of chemicals or a single chemical may be isolated from a botanical and sold as a dietary supplement, usually in tablet or capsule form. An example is phytoestrogens from soy products (11)

\section{Nutraceutical Concept with Varying Definition}

In Canada, this term is natural health products; in USA, it is called dietary supplements, and in Japan it is called foods for special health use. There are distinct definitions and regulations for dietary supplements and functional foods in USA, Canada, and Europe. Traditional and herbal medicines are included in the definition of dietary or nutritional supplements in Canada. Japan does not mention traditional herbal medicines under functional foods for special health use. USA includes herbal and botanical in its definition.

The Indian definition lists down the ingredients that a product should have, and it also specifies general properties of nutraceutical. There are three categories which have been considered under the nutraceuticals.

Functional Foods. Foods that have specific physiological benefits and/or reduce the risk of chronic disease, that is, nutrition fortified foods like fortified flour, fortified oil, fortified malt-based powder and probiotic foods like yogurt.

Dietary Supplements. Supplements provide nutrients that are missing or are not consumed in sufficient quantity in a person's diet, that is, vitamin supplements, mineral supplements, macronutrients, antioxidants, tonics, herbal formulations like Chyawanprash, Musli pak,
Ashwagandhadi leh, and nonherbal products like cod liver oil.

Functional Beverages. Liquids that quench thirst along with replenishing minerals provide energy, prevent ailments, and promote healthy life style, that is, sports and energy drinks, fortified juices, and glucose drinks and powder.

Nutraceutical products aim to fulfill specific needs of the persons based on which they may be classified as follows.

Enhancement segments: high protein supplements, energy drinks, sports drinks, glucose drinks, and so forth.

Specific condition segments: antioxidants, vitamin supplements, and mineral supplements.

Foundation segments: macronutrient supplements, nutrition fortified foods (fortified flour, soups, biscuits, etc.), probiotic foods (yogurt), and herbal formulations (chyawanprash, Ashwagandhadi leh) (12).

\section{Contribution of world health organization in the global acceptance of Ayurveda}

Department of AYUSH, Central Council of Research in Ayurveda and Siddha and numerous other collaborative centers of WHO in India are assigned with several Appraisal Project Work (APW) and Direct Financial Cooperation (DFC) projects that will strengthen Ayurveda as evidence-based medicine for its global acceptance.

World Health Organization (WHO) realized at Alma Ata in 1978 the role of traditional, alternative and complementary systems of medicine in the healthcare sectors of both developing and the developed nations with the slogan of "Health for All".

\section{Strengthening of Traditional Medicine by World Health Organization}

WHO is directing and coordinating with health authorities in respective countries around the globe and is responsible for providing leadership on global health matters, shaping the health research agenda, setting norms and standards, articulating evidence-based policy options, providing technical support to 
countries and monitoring and assessing health trends, and these responsibilities of WHO hold good for TRM too.

Specific Strategies
Considering all these issues, WHO is mainstreaming TRM in health system with definite strategies that cover each and every potential of TRM. [Table 1] Certain contributory steps of WHO are mentioned below.

Table 6 Specific strategies of WHO for promotion of TRM

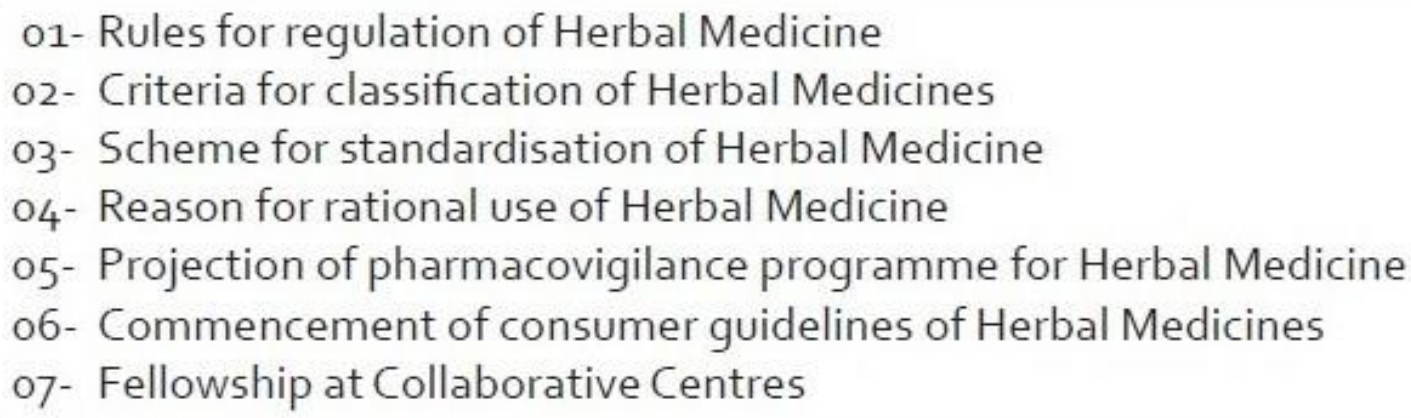

01- Rules for regulation of Herbal Medicine

o2- Criteria for classification of Herbal Medicines

03- Scheme for standardisation of Herbal Medicine

04- Reason for rational use of Herbal Medicine

05- Projection of pharmacovigilance programme for Herbal Medicine

o6- Commencement of consumer guidelines of Herbal Medicines

o7- Fellowship at Collaborative Centres

\section{Criteria for classification of herbal medicines}

As per the WHO guidelines, for all practical purposes, herbal medicines can be classified into four categories, based on their origin, evolution and the forms of current usage.

\section{Category 1: Indigenous herbal medicines}

This category of herbal medicines is historically used in the folklore of a local community or region and is very well known through ages by the local population in terms of its composition, treatment and dosage.

\section{Category 2: Herbal medicines in systems}

Medicines in this category have been used for a long time and are well documented with their special theories and concepts, and are duly accepted by the respective countries. For example, Ayurveda, Unani and Siddha fall into this category of TRM.

\section{Category 3: Modified herbal medicines}

These are herbal medicines as described above in categories 1 and 2, except that they have been modified in some way or the other with respect to their shape, dosage form, mode of administration, ingredients, and methods of preparation or medical indications. They have to meet the national regulatory requirements of safety and efficacy of herbal medicines.

\section{Category 4: Imported products with a herbal medicine base}

This category covers all imported herbal medicines including raw materials and products. Imported herbal medicines must be registered and marketed in the countries of origin. The safety and efficacy data have to be submitted to the national authority of the importing country and also need to meet the requirements of safety and efficacy of herbal medicines in the recipient country.

\section{Fellowship at collaborative centers}

Demand for herbal products worldwide has increased at an annual rate of $8 \%$ during the period of 1994-2001, and according to WHO forecast, the global herbal market would be worth $\$ 5$ trillion by the year 2050 . As of today, Europe and the United States are two major herbal product markets in the world, with a market share of $41 \%$ and $20 \%$, respectively. It seems that Ayurveda is undergoing a phase of resurgence and revival "in the world" similar to the one "at home".

\section{WHO, India and Ayurveda - A Reasonable Advancement}

Recently, in August 2010, Department of AYUSH of the Government of India has modified Rule 158 of The Drugs and Cosmetics Rules, 1945 to facilitate licensing and export of Ayurvedic herbal medicines under categories of Ayurvedic cosmeceuticals, Ayurvedic nutraceuticals and Ayurvedic extracts. 
For standard production of Ayurvedic medicines, WHO sponsored many Direct Financial Cooperative (DFC) projects in 2001 at Pharmacopeial Laboratory of Indian Medicine, projects on safety profile of Ayurvedic medicines in 2007 at Banaras Hindu University and WHO sponsored program for the planning of pharmacovigilance program in 2008 at Gujarat Ayurveda University. More recently, in 2010 and 2011, under DFC program, WHO had sponsored four capacity building training programs for coordinators of regional and peripheral centers of pharmacovigilance of Ayurvedic system of medicine. Further, Ayurvedic Clinical Trial project might be a sustainable program for evidence-based data generation of Ayurvedic classical medicines for certain diseases, whereas data available on Ayush Research Portal and in other research papers ensures safety of Ayurvedic medicines. In all these programs of Department of AYUSH, WHO is cooperating as an academic associate and also providing some logistic support (13).

\section{Opportunities and Challenges in Ayurveda: Global Perspective}

Modern medicine has failed miserably in developing robust preventive medicine.

India has over 500 teaching Hospitals, 700,000 Vaidyas and thousands of dispensaries. Ministry for AYUSH is trying to get World Health Organization (WHO) recognition for these facilities. Every year 30,000 Vaidyas are added to this pool. Global market size for herbal products exceeds 5000 billion, whereas Indian share of this market is just under $0.9 \%$ According to the experts the infrastructure at these AYUSH facilities are poor. In May of 2015, Ayurveda got a nod from the Swiss Government. Practitioners of Indian Traditional Medicine, Ayurveda will soon be able to get a federally approved diploma after passing an examination. The authorities in Switzerland hope that this will be bring credibility, especially in the eyes of the insurance providers. The first exams are to be held in November and applicants have to first pass a series of six pre-exams. Although these examinations are open to foreign nationals, it will be offered only in German, French and Italian (14).

\section{Traditional Medicine: The Goldmine for Modern Drugs}

In traditional systems, plant and plant products are used for the cure of diseases; however, in modern science the bioactive compounds of the plants are identified. These plants materials are being used for the development of modern drugs. It is believed that most of the drugs either traditionally used or used in modern science derived from natural sources. For the treatment of cancer, US Food and Drug Administration (FDA) has approved several drugs derived from natural sources. Of the 121 prescription drugs in use today for cancer treatment, 90 are derived from plants. At least 877 small-molecule drugs introduced worldwide between 1981 and 2002, most $(61 \%)$ can be traced back to their origins in natural products. These include Vincristine and Vinblastine (from Vinca rosea), Etoposide (from Mayapple), Irinotecan and Topotecan (from Camptotheca acuminata), Paclitaxel and Abraxane(from Taxus brevifolia), Solamargine (from Solanum dulcamara), Masoprocol (from Larrea tridentata), Arglabin (from Artemisia glabella), Alitretinoin (from Daucus carota) and others .

Moreover, there are numerous other natural compounds have shown chemopreventive and therapeutic efficacy and are in preclinical and clinical stage. One of the most widely studied molecules is curcumin, a component of turmeric. Turmeric is being used as a traditional medicine for the treatment of rheumatoid arthritis, chronic anterior uveitis, conjunctivitis, skin cancer, small pox, chicken pox, wound healing, urinary tract infections, and liver ailments. It is also being used against digestive disorders, jaundice, menstrual difficulties, and colic; for abdominal pain and distension; and for dyspeptic conditions including loss of appetite, postprandial feelings of fullness, and liver and gallbladder complaints. Many South Asian countries use it as an antiseptic for cuts, burns, and bruises, and as an antibacterial agent .Epidemiological and experimental studies suggested that curcumin is a pleiotropic molecule and can acts against wide varieties of diseases .Because of its safety and efficacy, the FDA has declared turmeric and its active component 
curcumin as GRAS (generally regarded as safe). Other traditionally used natural compound is guggulsterone derived from the gum resin (guggulu) of the tree Commiphora mukul. The resin has been used in Ayurvedic medicine for centuries to treat a variety of ailments, including obesity, bone fractures, arthritis, inflammation, cardiovascular disease and lipid disorders. Recent studies have shown that guggulsterone is an antagonist for the bile acid receptor farnesoid $\mathrm{X}$ receptor and regulating cholesterol homeostasis. It exhibits efficacy against inflammatory diseases by modulating various signaling molecules

There are other plant products have been used as a traditional medicine. Grape extracts have been used for human health over 2000 years ago in 'Darakchasava,' a well-known Indian herbal preparation whose main ingredient is Vitis vinifera $\mathrm{L}$. This 'Ayurvedic' medicine is prescribed as a cardiotonic and also is given for other disorders. Latter chemical analysis showed that it has an active component resveratrol, which has numerous activities against several diseases. It exhibits antioxidant, anti-inflammatory, antimicrobial, and anticancer properties. Another compound, flavopiridol, which is a semisynthetic flavonoid closely related to a compound originally isolated from the stem bark of Dysoxylum binectariferum. This plant indigenous to India and described in Ayurveda. Modern findings showed that flavopiridol is a potent inhibitor of cyclin-dependent kinases and acts against cancer and other chronic diseases. In Ayurveda, withanolide, which are extracted from Withania somnifera, are employed in the treatment of arthritis and menstrual disorders. This compound now investigated as potent inhibitors of angiogenesis, inflammation, tumor development, metastasis and oxidative stress, and a promoter of cardioprotection. The medicinal plant $W$. somnifera is widely known for its anti-inflammatory, cardioactive and neuroprotective effects. Boswellic acid, an active component of Boswellia serrata (also known as Salai guggul), is used in Indian traditional Ayurvedic medicine to treat rheumatic diseases, respiratory diseases and liver disorders. Extensive studies since last 30 years showed that the traditional therapeutic usefulness of Boswellic acid is a result of its anti-inflammatory activity, possibly mediated through the inhibition of 5-lipooxygenase and leukocyte elastase.

Besides these different formulations and extracts of fruits vegetables, spices, cereal, legumes and other parts of plants including leaf, root and bark are being used against various ailments in different traditional medicines around the world. In Chinese traditional medicines alone over three hundred herbs are commonly being used. Some of the most commonly used herbs are ginseng, wolfberry, dong quai, astragalus, atractylodes, bupleurum, cinnamon, coptis, ginger, hoelen, licorice, ephedra sinica, peony, rehmannia, rhubarb, and salvia. Similarly, in Korean, Unani and Native American traditional medicine systems hundreds of other plants are being used. Modern sciences are investigating the active components and mechanisms of action of these plant products and are in preclinical and clinical stage. Along with their efficacy, recent findings suggest that these herbal components are safe and cost effective. Because of their pharmacological safety, these agents can be used alone or as adjuncts to current chemotherapeutic agents to enhance therapeutic effects and minimize chemotherapy-induced toxicity. Since more than $80 \%$ of the world's population cannot afford modern medicines, the use of these herbal drugs either raw or in pure form (modern medicine) is appreciated. Thus the use of these drugs provided by Mother Nature could increase the life span by decreasing the cost and toxicity of modern drugs. (15-16).

\section{Conclusion}

Renewed public interest in complementary and alternative medicines come in to enforcement due to increased side effects, lack of curative treatment for several chronic diseases, high cost of new drugs, microbial resistance .

Now a days numerous nutraceutical combinations have entered the international market through exploration of ethnopharmacological claims made by different traditional practices.

In the current scenario, herbal drugs and their formulations have become an alternative to the 
synthetic drugs. The plant-derived natural products are the products of secondary metabolism; the compounds which are not essential for existence in laboratory conditions, but are certainly responsible for self-defense coordination in natural conditions.

Ninety percent of the daily diet should be made up of nutrient rich plant foods, whose calories are accompanied by health-promoting phytochemicals, vegetables, fresh fruits, beans and legumes, raw nuts, seeds, and avocados, starchy vegetables, and whole grains. These foods or nutraceuticals construct a healthpromoting, disease-preventing diet with protective substances. The rich nutrient food intake will provide maximum protection against not only infections, asthma, and allergies but also against heart disease and cancer in adulthood.

This new upsurge of interest in Ayurveda and its rapidly increasing public utilization has given rise to many newer issues and challenges.

\section{Abbreviations}

TRM- technical reference model

WHO- world health organization

BCE - Before the common Era /Before the current Era)

FDA -Food and drug Administration

AYUSH - The Ministry of Ayurveda, Yoga and Naturopathy, Unani, Siddha and Homoeopathy

\section{Acknowledgement}

The authors are thankful to IJIST Journal for publishing their article

\section{Conflicts of Interest}

The author declares that there are no conflicts of interest.

\section{References}

1. Asian Journal of Pharmaceutical and Clinical Research-History of Indian traditional medicines [Internet]. 2018 [cited 2019 Jan 03]. Available from:

https://www.researchgate.net/publication/32220710 1 ,

2. Wiki pedia -the free encyclopedia Ayrveda, illness portrayed [Internet]. 2019 [cited 2018 Oct 12]. Available from:

https://www.ncbi.nlm.nih.gov/pubmed/11253416

3. "Legal Status of Traditional Medicine and Complementary/Alternative Medicine: A Worldwide Review". World Health Organization (WHO) [Internet]. 2014 Jun [cited 2019 Jan 12]. Available from:

http://apps.who.int/medicinedocs/en/d/Jh2943e/

4. Wiki pedia -the free encyclopedia Ayrveda [Internet]. 2019 Jun [cited 2019 Jan 12]. Available from:

https://en.wikipedia.org/wiki/Ayurveda

5. Shukla N. Role of Ayurveda in Emergency Treatment Emergency [Internet]. 2012 Aug 27 [cited 2019 Jan 12]. Available from:

https://www.omicsonline.org/open-access/role-ofayurveda-in-emergency-treatment-2165-

7548.1000127.php?aid=8512

6. Pandey M. M., Rastogi S, Rawat A. K. S. Indian Traditional Ayurvedic System of Medicine and Nutritional Supplementation, Pharmacognosy \& Ethnopharmacology Division, CSIR-National Botanical Research Institute, Rana Pratap Marg, Lucknow 226001, India [Internet]. 2013 Jun [cited 2019 Jan 12]. Available from:

https://www.hindawi.com/journals/ecam/2013/3763 27/

7. Pandey M. M., Rastogi S, Rawat A. K. S. Indian Traditional Ayurvedic System of Medicine and Nutritional Supplementation, Pharmacognosy \& Ethnopharmacology Division, CSIR-National Botanical Research Institute, Rana Pratap Marg, Lucknow 226001, India [Internet]. 2013 Jun [cited 2019 Jan 13]. Available from:

https://www.hindawi.com/journals/ecam/2013/3763 27/tab1/

8. Pandey M. M., Rastogi S, Rawat A. K. S. Indian Traditional Ayurvedic System of Medicine and Nutritional Supplementation, Pharmacognosy \& Ethnopharmacology Division, CSIR-National Botanical Research Institute, Rana Pratap Marg, Lucknow 226001, India [Internet]. 2013 Jun [cited 2019 Jan 13]. Available from:

https://www.hindawi.com/journals/ecam/2013/3763 27/tab2/

9. Pandey M. M., Rastogi S, Rawat A. K. S. Indian Traditional Ayurvedic System of Medicine and Nutritional Supplementation, Pharmacognosy \& Ethnopharmacology Division, CSIR-National Botanical Research Institute, Rana Pratap Marg, Lucknow 226001, India [Internet]. 2013 Jun [cited 2019 Jan 13]. Available from:

https://www.hindawi.com/journals/ecam/2013/3763 27/tab3/

10. Pandey M. M., Rastogi S, Rawat A. K. S. Indian Traditional Ayurvedic System of Medicine and Nutritional Supplementation, Pharmacognosy \& Ethnopharmacology Division, CSIR-National Botanical Research Institute, Rana Pratap Marg, Lucknow 226001, India [Internet]. 2013 Jun [cited 2019 Jan 13]. Available from: 
https://www.hindawi.com/journals/ecam/2013/3763 27/fig 1

11. Guidance for Industry on Complementary and Alternative Medicine Products and Their Regulation by the Food and Drug Administration, U.S. Department of Health and Human Services Food and Drug Administration, Silver Spring, Md, USA [Internet]. 2006 [cited 2019 Jan 13]. Available from:

https://www.fda.gov/RegulatoryInformation/Guidan ces/ucm144657.htm

12. Pandey M. M., Rastogi S, Rawat A. K. S. Indian Traditional Ayurvedic System of Medicine and Nutritional Supplementation, Pharmacognosy \& Ethnopharmacology Division, CSIR-National Botanical Research Institute, Rana Pratap Marg, Lucknow 226001, India [Internet]. 2013 Jun [cited 2019 Jan 13]. Available from: http://www.ficci-nutraceuticals.com/

13. Chaudhary A, Singh N. Contribution of world health organization in the global acceptance of Ayurveda, [internet] oct-dec 2011 ,cited [11/01/19] ,available

from
https://www.ncbi.nlm.nih.gov/pmc/articles/PMC32 55448/

14. Gundu HR Rao,Opertunity and challenge : global perspective in Alternative \& Integrative Medicine [Internet]. 2017 Jun [cited 2019 Jan 13]. Available from:

https://www.omicsonline.org/open-

access/opportunities-and-challenges-in-ayurvedaglobal-perspective-2327-51621000239.php?aid=90627

15. Vhora I, Patil S, Bhatt P, Gandhi R, Baradia D, Misra A. Receptor-targeted drug delivery: current perspective and challenges. Therapeutic delivery. 2014;5(9):1007-24.

16. Prasad S, Tyagi, Sahdeo Prasad. Traditional Medicine: The Goldmine for Modern Drugs [Internet]. 2015 [cited 2019 Jan 12]. Available from:

https://www.omicsonline.org/openaccess/traditional-medicine-the-goldmine-formodern-drugs-2379-1764-3-e108.php?aid=40340 